\title{
Effect of Frozen Storage on the Water- Holding Capacity and pH of Broiler Chicken Cut-up Parts (Gallus gallus domesticus)
}

\author{
${ }^{a}$ Arjun Ghimire*, ${ }^{b}$ Pawan Parajuli \\ aDepartment of Food Technology, Central Campus of Technology, Tribhuvan University, Dharan, Nepal \\ bepartment of Food Technology, Dharan Multiple Campus, Tribhuvan University, Dharan, Nepal \\ *Corresponding email: arjun.ghimire@ cct.tu.edu.np
}

\begin{abstract}
Broiler chickens (Gallus gallus domesticus) were collected from local chicken suppliers of Dharan $\left(26.8065^{\circ} \mathrm{N}, 87.2846^{\circ} \mathrm{E}\right)$, Nepal, and slaughtered to prepare the cut-up parts (breast, drumstick, dorso, wings, and thigh). They were vacuum packed in polythene bags and frozen stored $\left(-21.5 \pm 3.5^{\circ} \mathrm{C}\right)$ for 45 days to study the effect of frozen storage on the water holding capacity (WHC) of meat. Cooking loss, drip loss, and $\mathrm{pH}$ changes were analyzed at 5 days intervals during storage and the data were analyzed using Genstat ${ }^{\circledR} \mathrm{v}$ 12.1.The cut-up parts showed a significant change $(\mathrm{p}<0.05)$ in $\mathrm{pH}$, cooking loss, and drip loss during 45 days of frozen storage. The $\mathrm{pH}$ decreased while the drip loss and the cooking loss increased gradually upon storage. The $\mathrm{pH}$ was found to be varied among the cut-up parts with a minimum $\mathrm{pH}$ scale of 5.25 for wings, followed by 5.3 for thigh, at the end. The highest drip loss of $6.11 \%$ was observed in wings after 5 days of storage which ended up to $8.97 \%$ after 45 days of frozen storage while drumstick and thigh samples showed significantly lower drip loss of $6.02 \%$, and $5.43 \%$ respectively. The change in cooking loss showed a similar pattern as that of drip loss with a significantly higher value of $37.36 \%$ in the breast while it showed no significant difference in drumstick, dorso, and thigh meat. Thus, the study reveals that freezing of broiler chicken meats for a prolonged period adversely affects the WHC of meat.
\end{abstract}

\begin{tabular}{l} 
Article Info \\
\hline Article history: \\
Received date: 18 May 2020 \\
Accepted date: 23 July 2020 \\
\hline \\
Keywords: \\
Broiler chickens \\
Cooking loss \\
Drip loss \\
Frozen storage \\
\end{tabular}

\section{Introduction}

Water holding capacity (WHC) is defined as the ability of meat and meat products to bind water during slicing, mincing, and pressing and also during transport, storage, processing, and cooking (Hamm, 1986). The water released can be described as drip, purge, weep, exudate, or cooking loss, and these are inversely related to WHC. The water released from a processed meat product is often described as cook yield, and this is directly related to WHC. WHC refers both to the bound water contained within the meat and also to water added during various operations connected with meat processing (Warner, 2017).

The majority of water in muscle is held within the structure of the muscle and muscle cells. Specifically, within the muscle cell, water is found within the myofibrils, between the myofibrils themselves and between the myofibrils and the cell membrane (sarcolemma), between muscle cells and between muscle bundles (Offer \& Knight, 1988). In general, water-soluble vitamins and minerals are dissolved in it. Entrapped water and free water in meat muscle can be easily removed by drying or can be converted into ice by freezing (Huff-Lonergan, 2019). This shows that meat is vulnerable to spoilage by microorganisms since there is a sufficient amount of nutrients available for their growth making it perishable. Thus, meat and meat products were historically among the most used food items to be packed and stored. Meat is frozen stored at $-18^{\circ}$ to $-25^{\circ} \mathrm{C}$ in normal commercial practice (Subba, 2010).

Nowadays, the air is evacuated from the packaging 
material before sealing to extend the shelf life of fresh meat sections or cuts and cured or processed meat products called as vacuum packaging. Vacuum packs are comprised of evacuated pouches or vacuum skin packs, in which a film of low gas permeability is closely applied to the surface of the product $\left(\mathrm{O}^{\prime}\right.$ Sullivan, 2017). Preservation effects are achieved by the development of an anaerobic environment within the pack (Bell et al., 1996). Packaging materials are principally made of plastic. Specifically, meat packaging should protect and maintain properties like appearance, water holding capacity, color, microbial quality, lipid stability, nutritive value, and sensorial aspects (McMillin, 2017). However, vacuum packaging harms chicken meat due to the application of shear force by vacuum increasing drip loss (Marcinkowska-Lesiak et al., 2016).

Freezing and frozen storage can produce profound effects on the structural and chemical properties of muscle foods, including changes in muscle fibers, lipids, and proteins, all of which have the potential for significantly influencing the quality attributes of meat and meat products (Miller et al., 1980). The structural changes that occur in muscle were reported, in a series of experiments, to be demonstrated the damaging effects of ice crystals growth on muscle fiber morphology (Luyet, 1959). Drip losses may increase during frozen storage (Awonorin \& Ayoade, 1992). During cooking, meat can lose a large quantity of its mass in the form of meat juice. Water loss determines the technological yield of the cooking operation, making it a critical factor in the industry. So, quality of raw and cooked meat are two different things as there are various changes in meat that occur after its cooking.

The objectives of the current analysis were to (i) study the physical and chemical properties of the cutup parts (ii) vacuum pack the cut-up parts and store at frozen condition $\left(-21.5 \pm 3.5^{\circ} \mathrm{C}\right)$, and (iii) examine the effects of frozen storage on cooking loss, $\mathrm{pH}$ and drip loss.

\section{Materials and Methods}

\subsection{Chicken preparation}

Live chickens (Gallus domesticus) weighing in the range of $2330 \mathrm{~g}$ to $3100 \mathrm{~g}$ were brought from the local chicken suppliers of Dharan $\left(26.8065^{\circ} \mathrm{N}, 87.2846^{\circ} \mathrm{E}\right)$. The chickens were slaughtered and cut-up parts were prepared as described by Subba (2010). The muscles were then aged at $4^{\circ} \mathrm{C}$ for $24 \mathrm{~h}$ and subjected to various chemical and physical analysis.

\subsection{Packaging material}

Regular polythene plastic (length $265 \mathrm{~mm}$, breadth $201 \mathrm{~mm}$, and thickness $3.00 \mu \mathrm{m}$ ) was used for vacuum packaging.

\subsection{Proximate analysis}

Moisture content and ash content were determined as per AOAC (2005). Similarly, crude fat, crude protein, and crude fiber were determined following the method described by Ranganna (2001).

\subsection{Water holding capacity and $\mathrm{pH}$}

WHC was determined by Grau and Hamm's method modified by (Hoffman et al., 1982). pH was determined using an electronic $\mathrm{pH}$ meter as per (AOAC, 2005).

\subsection{Vacuum packing and freezing}

The cut-up parts were vacuum-packed using regular polythene plastic. The Henan DZY260 with sealing time of 10-20s vacuum packing machine was used. The vacuum-packed cut-up parts were frozen in a nonventilated chamber and can, therefore, be considered slow-frozen. The samples were taken out from the freezer at a 5 day time interval for cooking loss, drip loss, and $\mathrm{pH}$ analysis.

\subsection{Cooking loss}

The prepared cut-up samples were taken out of the freezer at a 5-day interval of up to 45 days. The thickness of the sample was made $2.5 \mathrm{~cm}$ with a weight of $70 \mathrm{~g}$. The samples were then weighed, vacuum packed in a polythene bag and immersed in a thermostat-controlled water bath with circulating water at $75 \pm 5^{\circ} \mathrm{C}$. After $50 \mathrm{~min}$, the samples were removed from the water bath, cooled at room temperature, and placed on filter paper and the meat surface was airdried and cooking loss, CL can be calculated by below given expression (Subba,2010).

$$
C L=\frac{\mathrm{MR}-\mathrm{MC}}{\mathrm{MR}} \times 100 \%
$$

Where $M_{R}$ and $M_{C}$ are the weight before and after cooking.

\subsection{Drip loss}

Samples were taken from the freezers at 5 days intervals, weighed frozen, placed at room temperature and temperature of samples was allowed to come in equilibrium with room temperature. The thawed meat 
samples were removed from the packages, surface dried using blotting papers, and weighed to determine drip loss following the procedure of Benli (2016).

Drip loss (DL) can be calculated as:

$$
\mathrm{DL}=\frac{\mathrm{Wb}-\mathrm{Wa}}{\mathrm{Wb}} \times 100 \%
$$

Where $\mathrm{Wb}$ and $\mathrm{Wa}$ are the weight before and after thawing.

\subsection{Data analysis}

Means of the data, obtained after analysis of samples for cooking loss, drip loss and $\mathrm{pH}$, were differentiated using LSD (least significance difference) at a 5\% level of significance using Genstat version 12.1 .

\section{Results and Discussion}

\subsection{Cut-up parts of the chicken}

From the dressed body of slaughtered chickens, different cut-up parts were obtained as shown in Table 1. The average dressed weight of 10 chickens was $2076.7 \mathrm{~g}$ and the weights of cut-up parts were expressed in percentage based on the dressed weight.

Breast, thigh, drumstick, wings, and dorso constituted $45.17 \%, 14.89 \%, 10.55 \%, 10.15 \%$, and $19.30 \%$ of the dressed weight of the chickens respectively. The results closely agreed with the findings carried out by several researchers (Cevger et al., 2004; Soares et al., 2017).

Table 1: Cut-up parts of chicken based on dressed weight

\begin{tabular}{ll}
\hline Cut-up parts & Yields* \\
\hline Dressed weight $(\mathrm{g})$ & $2076.7 \pm 211.07$ \\
Breast (\%) & $45.17 \pm 3.59$ \\
Thigh (\%) & $14.89 \pm 1.99$ \\
Drumstick (\%) & $10.55 \pm 1.60$ \\
Wings (\%) & $10.15 \pm 0.82$ \\
Dorso (\%) & $19.30 \pm 3.50$ \\
\hline
\end{tabular}

* Provided yields are the means of data obtained from 10 chickens

Table 2: Chemical and physical characteristics of raw cut-up parts

\begin{tabular}{llllll}
\multicolumn{6}{c}{ Table 2: Chemical and physical characteristics of raw cut-up parts } \\
\hline Parameters & Drumstick $^{*}$ & Breast* $^{*}$ & Wings* $^{*}$ & Dorso $^{*}$ & Thigh* $^{*}$ \\
\hline Moisture (\%) & $74.99 \pm 1.67^{\mathrm{a}}$ & $75.74 \pm 1.73^{\mathrm{a}}$ & $75.84 \pm 1.87^{\mathrm{a}}$ & $74.65 \pm 2.04^{\mathrm{a}}$ & $73.84 \pm 1.54^{\mathrm{a}}$ \\
Ash (\%) & $1.78 \pm 0.39^{\mathrm{c}}$ & $1.40 \pm 0.05^{\mathrm{bc}}$ & $1.24 \pm 0.34^{\mathrm{ab}}$ & $0.836 \pm 0.14^{\mathrm{a}}$ & $1.34 \pm 0.29^{\mathrm{bc}}$ \\
Crude Protein (\%) & $19.17 \pm 1.21^{\mathrm{ab}}$ & $21.75 \pm 0.85^{\mathrm{b}}$ & $19.35 \pm 1.16^{\mathrm{ab}}$ & $18.93 \pm 0.73^{\mathrm{ab}}$ & $17.17 \pm 1.34^{\mathrm{a}}$ \\
Crude Fat (\%) & $3.55 \pm 0.65^{\mathrm{ab}}$ & $1.94 \pm 0.30^{\mathrm{a}}$ & $3.50 \pm 0.11^{\mathrm{ab}}$ & $4.10 \pm 0.28^{\mathrm{b}}$ & $6.71 \pm 0.96^{\mathrm{c}}$ \\
Crude fiber (\%) & $0.081 \pm 0.005^{\mathrm{ab}}$ & $0.091 \pm 0.007^{\mathrm{b}}$ & $0.074 \pm 0.007^{\mathrm{a}}$ & $0.076 \pm 0.001^{\mathrm{a}}$ & $0.074 \pm 0.006^{\mathrm{ab}}$ \\
Ultimate pH & $5.70 \pm 0.1^{\mathrm{a}}$ & $5.90 \pm 0.3^{\mathrm{ab}}$ & $5.75 \pm 0.07^{\mathrm{ab}}$ & $5.65 \pm 0.07^{\mathrm{b}}$ & $6.00 \pm 0.28^{\mathrm{a}}$ \\
WHC & $0.41 \pm 0.04^{\mathrm{a}}$ & $0.50 \pm 0.08^{\mathrm{b}}$ & $0.46 \pm 0.06^{\mathrm{ab}}$ & $0.48 \pm 0.02^{\mathrm{ab}}$ & $0.58 \pm 0.03^{\mathrm{c}}$ \\
\hline
\end{tabular}

\subsection{Chemical and physical parameters}

The cut-up parts were prepared and aged for about $24 \mathrm{~h}$ in chill condition $\left(4^{\circ} \mathrm{C}\right)$. Then, various chemical and physical parameters were analyzed in the laboratory. The chemical parameters included moisture, ash, crude protein, fat, and crude fiber content and the analytical results are tabulated in Table 2.

Moisture content in drumstick, breast, wings, dorso, and thigh were found to be $74.99 \%, 75.74 \%, 75.84 \%$, $74.65 \%$, and $73.84 \%$ respectively and no significant difference $(\mathrm{p}<0.05)$ was found between the moisture content of the cut-up parts. The meat samples of drumstick, breast, wings, dorso, and thigh contained respectively $1.78 \%, 1.40 \%, 1.24 \%$, and $0.836 \%$, and $1.34 \%$ ash. There was no significant difference between the ash content of breast and thigh whereas the ash content in drumstick, wings, and dorso was found to be significantly different. Crude protein contents in drumstick, breast, wings, dorso, and thigh meat were $19.17 \%, 21.75 \%, 19.35 \%, 18.93 \%$, and $17.17 \%$ respectively.

The protein content in the breast was found to be significantly higher than that in other cut-up parts. Crude fat contents of drumstick, breast, wings, dorso, and thigh meat were respectively $14.19 \%, 8.02 \%$, $14.50 \%, 16.17 \%$, and $25.65 \%$. Thigh meat contained a significantly higher quantity of fat than other cut-up parts. The dried and fat-free meat samples of drumstick, breast, wings, dorso, and thigh contained $0.38 \%, 0.41 \%, 0.36 \%, 0.36 \%$, and $0.38 \%$ crude fiber respectively. The ultimate $\mathrm{pH}$ of drumstick and thigh were found to be significantly higher $(\mathrm{p}<0.05)$ and the lowest $\mathrm{pH}$ was observed in dorso. The $\mathrm{pH}$ of breast and wings were 5.70 and 5.75 respectively.

\footnotetext{
*The results obtained are means of triplicate samples \pm standard deviations and different letters $(a-c)$ on the same row indicate significant difference at $p<0.05$.
} indicate significant difference at p< 0.05 . 
The water holding capacity (WHC) of drumstick, breast, wings, dorso, and thigh meat was found to be $0.41,0.50,0.46,0.48$, and 0.58 respectively. The water holding capacity of the thigh was found to be significantly higher than that of other cut-up parts and that of drumstick was significantly lower than that of other cut-up parts. These chemical characteristics were found similar to the study carried out by USDA (2019), Chepkemoi et al. (2017), and Sharma (1999). The ultimate $\mathrm{pH}$ did not vary with different cut-up parts. Results concerning the ultimate $\mathrm{pH}$ and WHC were compatible with the work of Puolanne (2017) and Basu et al. (2017).

\subsection{Effect of frozen storage on $\mathrm{pH}$}

The $\mathrm{pH}$ of all the meat samples to storage time was analyzed as shown in Table 3. Statistical analysis showed that frozen storage had a significant effect on the $\mathrm{pH}$ of different meat samples. As the frozen storage time increased, the $\mathrm{pH}$ of meat samples decreased significantly $(\mathrm{p}<0.05)$. The $\mathrm{pH}$ values after 24 hours of slaughter were significantly different than those of 45 days of frozen stored meat samples for all the cutup parts. This decline in $\mathrm{pH}$ can be correlated with the results reported by Basu et al. (2017) where the $\mathrm{pH}$ of chicken breast meat declined with respect to storage time at the freezing condition.

The $\mathrm{pH}$ values of drumstick and thigh were found to be significantly higher than the $\mathrm{pH}$ values of other cut-up parts at day 0 (where the meat samples were not frozen stored). On the 45th day of frozen storage, there was no significant difference between the $\mathrm{pH}$ of breast, drumstick, and dorso meat and between the $\mathrm{pH}$ of thigh and wings meat. The difference may be due to the different types of muscle that predominate in the thigh meat (oxidative vs glycolytic muscles in the breast), or it may be due to change in the proportion of the muscle fiber that is responsible for a different pattern of muscle metabolism. The decrease variation in $\mathrm{pH}$ value may be attributed to the breakdown of glycogen with the formation of lactic acid and the increase of $\mathrm{pH}$ that may be due to the partial proteolysis leading to the increase of free alkaline groups depending on the condition of such changes (Puolanne, 2017).

Leygonie et al. (2012) found that, with the proper freezing storage conditions, the $\mathrm{pH}$ of meat decreases with increasing storage duration which is attributable to the loss of water with its associated soluble substances, denaturation of buffer proteins and the accumulation of acidic products of ongoing transformational processes such as deamination of proteins by microbial or enzymatic action, with the ensuring release of the hydrogen atom. This declination of $\mathrm{pH}$ of vacuum-packed cut-up parts with respect to frozen storage time appreciates the result obtained by Poławska et al. (2014).

\subsection{Effect of frozen storage on drip loss}

Drip losses were calculated using equation 2 and the results are presented in Table 4. It can be seen that there was a significant increase $(p<0.05)$ in drip losses in all the cut-up parts as the frozen storage time preceded. The drip loss of breast meat was $5.71 \%$ on the $5^{\text {th }}$ day of frozen storage, which significantly increased to $7.48 \%$ on the $45^{\text {th }}$ day of frozen storage. There was a significant increase in drip loss in drumstick from $3.01 \%$ on the $5^{\text {th }}$ day to $6.02 \%$ on the $45^{\text {th }}$ day of frozen storage. The drip loss in dorso meat increases significantly from $4.97 \%$ to $7.23 \%$.

Table 3: $\mathrm{pH}$ of cut-up parts at different frozen storage times (days)

\begin{tabular}{|c|c|c|c|c|c|c|c|c|c|c|}
\hline \multirow{2}{*}{$\begin{array}{l}\text { Cut-up } \\
\text { parts }\end{array}$} & \multicolumn{10}{|c|}{ pH at different frozen storage times (days) } \\
\hline & $\mathbf{0}$ & 5 & 10 & 15 & 20 & 25 & 30 & 35 & 40 & 45 \\
\hline \multirow[t]{2}{*}{ Breast } & $5.70 \pm$ & $5.50 \pm$ & $5.57 \pm$ & $5.53 \pm$ & $5.37 \pm$ & $5.43 \pm$ & $5.25 \pm$ & $5.37 \pm$ & $5.40 \pm$ & $5.43 \pm$ \\
\hline & $0.10^{\mathrm{a}}$ & $0.10^{\mathrm{a}}$ & $0.15^{\mathrm{a}}$ & $0.05^{\mathrm{a}}$ & $0.15^{\mathrm{b}}$ & $0.15^{\mathrm{ab}}$ & $0.05^{\mathrm{c}}$ & $0.06^{\mathrm{b}}$ & $0.20^{\mathrm{ab}}$ & $0.32^{\mathrm{ab}}$ \\
\hline \multirow[t]{2}{*}{ Drumstick } & $5.90 \pm$ & $5.75 \pm$ & $5.70 \pm$ & $5.55 \pm$ & $5.65 \pm$ & $5.55 \pm$ & $5.50 \pm$ & $5.45 \pm$ & $5.45 \pm$ & $5.45 \pm$ \\
\hline & $0.30^{\mathrm{a}}$ & $0.07^{\mathrm{b}}$ & $0.14^{\mathrm{b}}$ & $0.35^{\mathrm{ab}}$ & $0.07^{\mathrm{a}}$ & $0.2^{\mathrm{ab}}$ & $0.14^{\mathrm{ab}}$ & $0.07^{\mathrm{b}}$ & $0.2^{\mathrm{b}}$ & $0.07^{\mathrm{b}}$ \\
\hline \multirow[t]{2}{*}{ Dorso } & $5.65 \pm$ & $5.45 \pm$ & $5.40 \pm$ & $5.45 \pm$ & $5.45 \pm$ & $5.50 \pm$ & $5.45 \pm$ & $5.40 \pm$ & $5.40 \pm$ & $5.55 \pm$ \\
\hline & $0.07^{\mathrm{a}}$ & $0.07^{b}$ & $0.14^{\mathrm{b}}$ & $0.07^{\mathrm{b}}$ & $0.07^{\mathrm{b}}$ & $0.14^{\mathrm{b}}$ & $0.21^{\mathrm{b}}$ & $0.00^{\mathrm{b}}$ & $0.14^{\mathrm{b}}$ & $0.07^{b}$ \\
\hline \multirow[t]{2}{*}{ Thigh } & $6.00 \pm$ & $5.75 \pm$ & $5.65 \pm$ & $5.75 \pm$ & $5.55 \pm$ & $5.60 \pm$ & $5.80 \pm$ & $5.35 \pm$ & $5.40 \pm$ & $5.30 \pm$ \\
\hline & $0.28^{a}$ & $0.21^{\mathrm{ab}}$ & $0.07^{\mathrm{ab}}$ & $0.07^{\mathrm{ab}}$ & $0.07^{\mathrm{ab}}$ & $0.28^{\mathrm{b}}$ & $0.14^{\mathrm{ab}}$ & $0.07^{\mathrm{c}}$ & $0.28^{b c}$ & $0.14^{\mathrm{c}}$ \\
\hline \multirow[t]{2}{*}{ Wings } & $5.75 \pm$ & $5.50 \pm$ & $5.60 \pm$ & $5.55 \pm$ & $5.45 \pm$ & $5.40 \pm$ & $5.35 \pm$ & $5.55 \pm$ & $5.45 \pm$ & $5.25 \pm$ \\
\hline & $0.07^{\mathrm{a}}$ & $0.14^{\mathrm{ab}}$ & $0.14^{\mathrm{b}}$ & $0.07^{\mathrm{a}}$ & $0.07^{b c}$ & $0.14^{\mathrm{bc}}$ & $0.07^{\mathrm{c}}$ & $0.28^{\mathrm{a}}$ & $0.07^{\mathrm{bc}}$ & $0.07^{\mathrm{c}}$ \\
\hline
\end{tabular}

* The results obtained are means of triplicate samples \pm standard deviations and values having different letters on the same row $(a-c)$ indicate significant difference at $p<0.05$. 
In thigh meat, it was seen that drip loss was $3.14 \%$ on the $5^{\text {th }}$ day and $5.43 \%$ on the $45^{\text {th }}$ day of frozen storage. The drip loss of wings meat was $6.11 \%$ on the $5^{\text {th }}$ day of frozen storage, which significantly increased to $8.97 \%$ on the $45^{\text {th }}$ day of frozen storage.

The significant difference was seen between the drip losses of different cut-up parts as well at $p<0.05$. On the 5th day of frozen storage, the drip losses of drumstick and thigh meat were significantly lower than that of the breast, dorso, and wings meat samples. The difference in drip losses between the cut-up parts varied as the frozen storage time preceded. On the 45th day, the drip loss as observed in wings meat was significantly higher than that in other parts and lowest in drumstick and thigh meat. This variation in drip losses can be explained by the variation in the $\mathrm{pH}$ of meat samples. On the 45th day, the $\mathrm{pH}$ of wings meat was significantly at $p<0.05$ than that of other cut-up parts. Lawrie (1959) showed the relationship between the ultimate $\mathrm{pH}$ in longissimus and psoas muscles and the extent of drip on thawing of the beef where drip loss increases as a decrease in ultimate $\mathrm{pH}$.

Ice crystals formed within the I-band, but not within the A-band at $-22^{\circ} \mathrm{C}$, possibly because the WHC of the actin filaments is weaker than that of myosin filaments, and the difference can be elicited in this temperature range. Xiong (1997) suggests that freezing affects the fiber due to the distortion and damage by the growth of ice crystals inside the muscular tissues. Xiong (1997) also explains that protein damage is generally a function of time and temperature of freezing. In general, the extent of denaturation of both sarcoplasmic and myofibrillar proteins increases with the length of frozen storage. In addition to physical damage by ice crystals and destabilization by concentrated solutes, muscle proteins during meat frozen storage and thawing are susceptible to oxidation, which further contributes to drip loss in thawed meat (Utera et al., 2014). Furthermore, HuffLonergan \& Lonergan (2005) explain potential changes in muscle fiber diameter during aging as influenced by proteolysis influencing drip formation. Besides, drip loss increase with the increase in storage time as explained by Poławska et al. (2014) and Marcinkowska-Lesiak et al. (2016).

\subsection{Effect of frozen storage on cooking loss}

The aged cut-up parts were subjected to cooking in polyethylene bags. At first, unfrozen and unpacked samples were subjected to analysis for cooking loss in a water bath. Those samples were just used to analyze cooking loss before frozen storage and vacuum packing. The vacuum-packed and frozen stored samples were also tested for cooking loss in the time interval of 5 days. The cooking losses were determined using equation 2 and are tabulated in Table 5.

At the initial stage, it was found that breast, dorso, and wings meat had significantly higher cooking losses than the other cut-up parts while the thigh meat had the lowest cooking loss. There was significant $(p<0.05)$ inclination in cooking loss as the frozen storage proceeded upon storage. On the 45th day, cooking loss of breast meat reached $37.36 \%$ which was the highest $(p<0.05)$ among the different cut-up parts. The cooking loss of drumstick meat increased from $15.39 \%$ to $30.46 \%$ over 45 days of frozen storage. The dorso meat lost $29.31 \%$ fluid as a cooking loss on the 45th day of frozen storage which was significantly higher than cooking loss on day 0 and day 5 of frozen storage.

Table 4: Drip losses of cut-up parts at different frozen storage times (days)

\begin{tabular}{llllllllll}
\hline Cut-up parts & \multicolumn{7}{c}{ Drip losses at different frozen storage times (days) } \\
\cline { 2 - 9 } & $\mathbf{5}$ & $\mathbf{1 0}$ & $\mathbf{1 5}$ & $\mathbf{2 0}$ & $\mathbf{2 5}$ & $\mathbf{3 0}$ & $\mathbf{3 5}$ & $\mathbf{4 0}$ & $\mathbf{4 5}$ \\
\hline Breast & $5.71 \pm$ & $7.10 \pm$ & $5.82 \pm$ & $5.84 \pm$ & $5.79 \pm$ & $7.02 \pm$ & $8.06 \pm$ & $8.05 \pm$ & $7.48 \pm$ \\
& $0.83^{\mathrm{a}}$ & $1.57^{\mathrm{b}}$ & $0.91^{\mathrm{a}}$ & $1.95^{\mathrm{a}}$ & $1.33^{\mathrm{a}}$ & $1.55^{\mathrm{b}}$ & $1.85^{\mathrm{c}}$ & $1.88^{\mathrm{c}}$ & $1.42^{\mathrm{b}}$ \\
Drumstick & $3.01 \pm$ & $4.97 \pm$ & $4.74 \pm$ & $5.53 \pm$ & $4.51 \pm$ & $5.40 \pm$ & $4.62 \pm$ & $6.08 \pm$ & $6.02 \pm$ \\
& $0.78^{\mathrm{a}}$ & $1.30^{\mathrm{ab}}$ & $0.51^{\mathrm{ab}}$ & $0.69^{\mathrm{ab}}$ & $0.11^{\mathrm{ab}}$ & $0.69^{\mathrm{ab}}$ & $1.05^{\mathrm{ab}}$ & $0.17^{\mathrm{b}}$ & $0.04^{\mathrm{b}}$ \\
Dorso & $4.97 \pm$ & $3.98 \pm$ & $5.93 \pm$ & $6.29 \pm$ & $5.24 \pm$ & $7.05 \pm$ & $5.80 \pm$ & $4.92 \pm$ & $7.23 \pm$ \\
& $1.30^{\mathrm{ab}}$ & $1.35^{\mathrm{a}}$ & $0.11^{\mathrm{ab}}$ & $1.88^{\mathrm{ab}}$ & $0.91^{\mathrm{ab}}$ & $1.10^{\mathrm{b}}$ & $2.00^{\mathrm{ab}}$ & $0.15^{\mathrm{ab}}$ & $0.91^{\mathrm{b}}$ \\
Thigh & $3.14 \pm$ & $3.45 \pm$ & $4.67 \pm$ & $5.00 \pm$ & $6.70 \pm$ & $4.61 \pm$ & $6.01 \pm$ & $5.83 \pm$ & $5.43 \pm$ \\
& $0.96^{\mathrm{a}}$ & $0.61^{\mathrm{a}}$ & $0.41^{\mathrm{ab}}$ & $1.35^{\mathrm{ab}}$ & $1.55^{\mathrm{b}}$ & $1.99^{\mathrm{ab}}$ & $0.13^{\mathrm{ab}}$ & $1.92^{\mathrm{ab}}$ & $1.95^{\mathrm{ab}}$ \\
Wings & $6.11 \pm$ & $5.97 \pm$ & $5.96 \pm$ & $5.50 \pm$ & $5.78 \pm$ & $6.25 \pm$ & $6.49 \pm$ & $7.95 \pm$ & $8.97 \pm$ \\
& $2.69^{\mathrm{a}}$ & $0.22^{\mathrm{a}}$ & $0.22^{\mathrm{a}}$ & $2.39^{\mathrm{a}}$ & $0.94^{\mathrm{a}}$ & $1.71^{\mathrm{a}}$ & $3.04^{\mathrm{a}}$ & $1.79^{\mathrm{b}}$ & $2.62^{\mathrm{b}}$ \\
\hline
\end{tabular}

$*$ The results obtained are means of triplicate samples \pm standard deviations and values having different letters on the same row $(a-c)$ indicate significant difference at $p<0.05$. 
Table 5: Cooking losses of cut-up parts at different frozen storage times (days)

\begin{tabular}{lllllllllll}
\hline \multirow{2}{*}{$\begin{array}{l}\text { Cut-up } \\
\text { parts }\end{array}$} & \multicolumn{8}{c}{ Cooking losses at different frozen storage times (days) } \\
\cline { 2 - 10 } & $\mathbf{0}$ & $\mathbf{5}$ & $\mathbf{1 0}$ & $\mathbf{1 5}$ & $\mathbf{2 0}$ & $\mathbf{2 5}$ & $\mathbf{3 0}$ & $\mathbf{3 5}$ & $\mathbf{4 0}$ & $\mathbf{4 5}$ \\
\hline Breast & $20.95 \pm$ & $25.73 \pm$ & $24.98 \pm$ & $29.63 \pm$ & $28.55 \pm$ & $31.40 \pm$ & $34.70 \pm$ & $33.55 \pm$ & $36.50 \pm$ & $37.36 \pm$ \\
& $1.02^{\mathrm{a}}$ & $0.77^{\mathrm{bc}}$ & $0.59^{\mathrm{b}}$ & $1.29^{\mathrm{cde}}$ & $0.75^{\mathrm{bcd}}$ & $2.04^{\mathrm{deg}}$ & $1.05^{\mathrm{fg}}$ & $0.95^{\mathrm{efg}}$ & $1.34^{\mathrm{gb}}$ & $1.41^{\mathrm{g}}$ \\
Drumstick & $15.39 \pm$ & $20.18 \pm$ & $21.53 \pm$ & $22.73 \pm$ & $26.73 \pm$ & $26.18 \pm$ & $29.07 \pm$ & $28.79 \pm$ & $30.52 \pm$ & $30.46 \pm$ \\
& $1.39^{\mathrm{a}}$ & $1.62^{\mathrm{ab}}$ & $2.54^{\mathrm{ab}}$ & $3.08^{\mathrm{ab}}$ & $2.97^{\mathrm{b}}$ & $2.04^{\mathrm{b}}$ & $0.20^{\mathrm{b}}$ & $1.94^{\mathrm{b}}$ & $2.59^{\mathrm{b}}$ & $1.11^{\mathrm{b}}$ \\
Dorso & $19.15 \pm$ & $25.77 \pm$ & $24.86 \pm$ & $24.42 \pm$ & $23.39 \pm$ & $27.05 \pm$ & $27.98 \pm$ & $28.22 \pm$ & $28.14 \pm$ & $29.31 \pm$ \\
& $1.87^{\mathrm{a}}$ & $2.44^{\mathrm{ab}}$ & $1.03^{\mathrm{ab}}$ & $0.93^{\mathrm{ab}}$ & $1.34^{\mathrm{ab}}$ & $1.41^{\mathrm{b}}$ & $1.38^{\mathrm{b}}$ & $2.03^{\mathrm{b}}$ & $0.46^{\mathrm{b}}$ & $1.39^{\mathrm{b}}$ \\
Thigh & $12.07 \pm$ & $16.24 \pm$ & $17.79 \pm$ & $24.21 \pm$ & $22.68 \pm$ & $23.45 \pm$ & $27.45 \pm$ & $26.31 \pm$ & $30.55 \pm$ & $29.45 \pm$ \\
& $0.48^{\mathrm{a}}$ & $0.86^{\mathrm{ab}}$ & $1.76^{\mathrm{abc}}$ & $2.07^{\mathrm{cd}}$ & $1.47^{\mathrm{bcd}}$ & $1.70^{\mathrm{bcd}}$ & $1.41^{\mathrm{d}}$ & $1.32^{\mathrm{d}}$ & $3.04^{\mathrm{d}}$ & $1.02^{\mathrm{d}}$ \\
Wings & $20.82 \pm$ & $25.04 \pm$ & $25.44 \pm$ & $27.59 \pm$ & $27.41 \pm$ & $31.34 \pm$ & $32.16 \pm$ & $33.05 \pm$ & $33.09 \pm$ & $34.05 \pm$ \\
& $1.32^{\mathrm{a}}$ & $4.65^{\mathrm{ab}}$ & $1.14^{\mathrm{ab}}$ & $1.59^{\mathrm{ab}}$ & $1.35^{\mathrm{b}}$ & $1.30^{\mathrm{b}}$ & $0.87^{\mathrm{b}}$ & $0.60^{\mathrm{b}}$ & $2.01^{\mathrm{b}}$ & $1.38^{\mathrm{b}}$ \\
\hline
\end{tabular}

*The results obtained are means of triplicate samples \pm standard deviations and values having different letters on the same row (a-g) indicate significant difference at $p<0.05$.

Thigh meat also showed a significant inclination in cooking loss from 12.07 to $29.45 \%$ on the 45 th day of frozen storage. Lastly, wings meat lost $34.05 \%$ fluid on the 45th day of frozen storage. A similar result was obtained by Basu et al. (2017) and Giampietro-Ganeco et al. (2017) in frozen stored broiler breast meat.

Table 5 showed that the cooking loss of fresh samples was comparatively lower than that of vacuumpacked and frozen stored samples. The results obtained are in accordance with the results of a study on chicken meat by Basu et al. (2017) and Giampietro-Ganeco et al. (2017). Rahelic et al. (1985) explained the formation of ice both inter- and intra-cellular at $-22^{\circ} \mathrm{C}$ when the greatest structural damage was observed. At this temperature, the solubility of the myofibrillar protein was also found to be the least. Ice crystals formed within the I-band, but not within the A-band at $-22^{\circ} \mathrm{C}$, possibly because the $\mathrm{WHC}$ of the actin filaments is weaker than that of myosin filaments, and the difference can be elicited in this temperature range. Xiong (1997) suggests that freezing affects the fiber due to the distortion and damage by the growth of ice crystals inside the muscular tissues. Xiong (1997) explained that protein damage is generally a function of time and temperature of freezing. In general, the extent of denaturation of both sarcoplasmic and myofibrillar proteins increases with the length of frozen storage. In addition to physical damage by ice crystals and destabilization by concentrated solutes, muscle proteins during meat frozen storage and thawing are susceptible to oxidation, which further contributes to drip loss and cooking loss in thawed meat (Utera et al., 2014).

\section{Conclusions}

Broiler chickens (Gallus gallus domesticus) from local chicken suppliers of Dharan, Nepal were brought and slaughtered to prepare cut-up parts (breast, drumstick, dorso, wings, and thigh). The results revealed that breast constitutes the highest weight of dressed chicken body whereas wings, the lowest. The moisture contents in all the cut-up parts were in prominent amounts showing no significant difference $(\mathrm{p}<0.05)$ among them. Breast contained the maximum protein with the lowest fat content. The frozen storage time had a significant effect on the $\mathrm{pH}$ of chicken meat and the lowest ultimate $\mathrm{pH}$ was observed in wings. The drop in $\mathrm{pH}$ affected negatively on the water holding capacity of meat. The highest drip loss was observed in the wings while drumstick and thigh samples showed significantly lower drip loss. Both the cooking loss and drip loss increased significantly with an increase in frozen storage time and the highest cooking loss was identified in the breast. The result showed that the long term storage of meat in freezing condition lowers the WHC of meat.

\section{Acknowledgments}

The authors appreciate all the faculties and staff of the Dharan Multiple Campus, Dharan, Nepal for their support and technical assistance.

\section{Conflicts of Interest}

The authors state no conflicts of interest. The authors alone are responsible for composing the paper.

\section{Funding}

This research did not get a particular award or grant from subsidizing organizations in general society, business, or not-for-profit driven sectors. 


\section{References}

AOAC. (2005). Official method of analysis. In Association of Official Analytical Chemists (18 ed., pp. 376-377).

Awonorin, S. O., \& Ayoade, J. A. (1992). Texture and eating quality of raw-and thawed-roasted turkey and chicken breasts as influenced by age of birds and period of frozen storage. Foodservice Research International, 6(4), 241-255.

Basu, A., Basu, S. K., Sengupta, R., Asif, M., Li, X., Li, Y., Hirani, A., Zandi, P., Sajad, M., \& SolorioSánchez, F. (2017). Important Plant-Based Phytonutrients. Phytonutritional Improvement of Crops, https://doi.org/10.1002/9781119079972.ch1

Bell, R. G., Penny, N., \& Moorhead, S. M. (1996). The retail display life of steaks prepared from chill stored vacuum and carbon dioxide-packed subprimal beef cuts. Meat science, 42(2), 165-178.

Benli, H. (2016). Consumer attitudes toward storing and thawing chicken and effects of the common thawing practices on some quality characteristics of frozen chicken. Asian-Australasian journal of animal sciences, $29(1), \quad 100$. https://dx.doi.org/10.5713\%2Fajas.15.0604

Cevger, Y., SARIÖZKAN, S., \& Güler, H. (2004). The effect of the sale of whole or cut up chicken meat on enterprise income according to season. Turkish Journal of Veterinary and Animal Sciences, 28(2), 399-402.

Chepkemoi, M., Macharia, J. W., Sila, D., Oyier, P., Malaki, P., Ndiema, E., Agwanda, B., Obanda, V., Ngeiywa, K. J., \& Lichoti, J. (2017). Physical characteristics and nutritional composition of meat and eggs of five poultry species in Kenya. 29, 153. http://www.lrrd.org/lrrd29/8/somm29153.html

Giampietro-Ganeco, A., Owens, C. M., Mello, J. L. M., Souza, R. A., Ferrari, F. B., Souza, P. A., \& Borba, H. (2017). Physical and chemical characteristics of meat from broilers raised in 4 different rearing systems, stored under freezing for up to 12 months. 1-9. https://doi.org/10.3382/ps/pex183

Hamm, R. (1986). Functional properties of the myofibrillar system and their measurements. In P. J. Bechtel (Ed.), Muscle as Food (pp. 135-199). Academic Press.
Hoffman, K., Hamm, R., \& Bluchel, E. (1982). Determination of the water binding of the meat with the aid of the filter paper method. (62), 87-92.

Huff-Lonergan, E. (2019, 22 April, 2010). WaterHolding Capacity of Fresh Meat. https://articles.extension.org/pages/27339/waterholding-capacity-of-fresh-meat\#Freeze.2FThaw

Huff-Lonergan, E., \& Lonergan, S. (2005). Mechanisms of water-holding capacity of meat: the role of postmortem biochemical and structural changes. $71, \quad 194-204$. https://doi.org/10.1016/j.meatsci.2005.04.022

Lawrie, R. A. (1959). Water-binding capacity and drip formation in meat. Journal of refrigeration, 2, 8789.

Leygonie, C., Britz, T. J., \& Hoffman, L. C. (2012). Impact of freezing and thawing on the quality of meat: $\quad$ Review. 93, 93-98. https://doi.org/10.1016/j.meatsci.2012.01.013

Luyet, B. (1959). The freezing of tissues as seen at the molecular level. Proc. Meat Ind. Res. Conf,

Marcinkowska-Lesiak, M., Zdanowska-Sąsiadek, Z., Stelmasiak, A., Damaziak, K., Michalczuk, M., Poławska, E., Wyrwisz, J., \& Wierzbicka, A. (2016). Effect of packaging method and coldstorage time on chicken meat quality. 14(1), 41-46. https://doi.org/doiI:10.1080/19476337.2015.10420 54

McMillin, K. W. (2017). Advancements in meat packaging. Meat science, 132, 153-162.

Miller, A. J., Ackerman, S. A., \& Palumbo, S. A. (1980). Effects of frozen storage on functionality of meat for processing. Journal of Food Science, 45(6), 1466-1471.

O' Sullivan, M. G. (2017). Packaging technologies for maintaining sensory quality. In A Handbook for Sensory and Consumer-Driven New Product Development (1st ed., Vol. II, pp. 125-149). Woodhead Publishing

Offer, G., \& Knight, P. (1988). The structural basis of water-holding capacity in meat. Part 2: drip losses. In R. Lawrie (Ed.), Developments in Meat Science (Vol. 4, pp. 173-243). Elsevier Science Publications.

Poławska, E., Półtorak, A., Wyrwisz, J., Wierzbicka, A., Gutkowska, K., Pomianowski, J., \& De Smet, S. 
(2014). The physical traits and fatty acids profile of ostrich meat enriched in $\mathrm{n} 3$ fatty acids as influenced by duration of refrigerated storage and type of packaging. 4, 351-358.

Puolanne, E. (2017). Developments in our understanding of water-holding capacity in meat. In P. P. Purslow (Ed.), New Aspects of Meat Quality (pp. 167-190). Woodhead Publishing

Rahelic, S., Puac, S., \& Gawwad, A. H. (1985). Structure of beef longissimus dorsi muscle frozen at various temperatures: Part 1. 14, 63-72. https://doi.org/10.1016/0309-1740(85)90082-8

Ranganna, S. (2001). Proximate analysis, color measurement and sensory evaluation. Handbook of analysis and quality control of fruits and vegetable products, 32-150.

Sharma, B. D. (1999). Meat and Meat Products Technology (Including Poultry Products Technology) (1st ed.). Jaypee Brothers Medical Publishers.

Soares, C., Dahlke, F., Netto, D., \& Scussel, V. (2017). Chicken (Gallus gallus domesticus L.) Cuts Yield
Specifics of Cobb 500 Slow and Hubbard Flex Hybrids. https://doi.org/10.5923/j.fph.20170701.03

Subba, D. (2010). Textbook of Meat and Poultry Technology (First ed.). National College of Food Science and Technology.

USDA. (2019). The nutritional value of chicken. National Chicken Council, Washington. https://www.nationalchickencouncil.org/chickenthe-preferred-protein-for-your-health-andbudget/the-nutritional-value-of-chicken/

Utera, M., Parra, V., \& Estevez, M. (2014). Protein oxidation during frozen storage and subsequent processing of different beef muscles. 96, 812-820. https://doi.org/10.1016/j.meatsci.2013.09.006

Warner, R. D. (2017). The eating quality of meat-IV water-holding capacity and juiciness. In F. Toldra (Ed.), Food Science, Technology and Nutrition, Lawrie's Meat Science (8th ed., pp. 419-459). Woodhead Publishing Series.

Xiong, Y. L. (1997). Protein denaturation and functionality losses. In M. C. Erickson \& Y. C. Hung (Eds.), Quality in Frozen Foods (pp. 111140). Chapman \& Hall.

(C) 2020 by the authors. Submitted for possible open access publication under the terms and conditions of the Creative Commons Attribution (CC BY) license (http://creativecommons.org/licenses/by/4.0/).

How to cite: Ghimire, A., \& Parajuli, P. (2020). Effect of Frozen Storage on the Water- Holding Capacity and $\mathrm{pH}$ of Broiler Chicken Cut-up Parts (Gallus gallus domesticus). Himalayan Journal of Science and Technology, $3-4,8-15$. 